\title{
Specificity of energetic functioning of economic activity objects
}

\author{
Karol Bednarek ${ }^{1, *}$, Artur Bugala ${ }^{1}$, Dorota Typanska ${ }^{1}$, and Leszek Kasprzyk ${ }^{1}$ \\ ${ }^{1}$ Poznan University of Technology, Institute of Electrical Engineering and Electronics, Piotrowo 3a \\ Street, 60-965 Poznań, Poland
}

\begin{abstract}
Ecology is strongly related to the quality of energy management and to limiting the negative impact of the technosphere on the environment. This work refers to the analysis of energy quality and power balances in different, due to the specificity of functioning (used electrical equipment), business facilities. The research was carried out for supply networks: in the bank building, in the IT laboratory and in the office and warehouse facility. The measurements of currents, voltages, active, reactive and apparent power in individual phases of power supply system as well as distortions (higher harmonics) of currents and voltages were carried out. The research was carried out to identify irregularities in the networks and to indicate ways to limit the effects of electromagnetic disturbances (mainly higher harmonics) as well as achieve improvements in energy efficiency and ecology in the operation of these facilities.
\end{abstract}

\section{Introduction}

Many recent decades in the world are associated with civilization and technical development. Human enormously introduces in all areas of existence devices and technical systems that simplify the economic activity as well as private life. The devices require energy supply for their functioning; materials are used in production processes, and additionally often have a negative impact on the environment. For these reasons, all pro-ecological activities aimed at protecting the natural environment are very important. They are mainly related to the optimization of resources and energy management as well as limiting negative effects of the technosphere on the environment [1-6].

The paper deals with power balances and distortions of currents and voltages in supply networks for various types of business units. Physical tests and analysis of energy consumption and effect of electromagnetic disturbances (especially higher harmonics) were carried out in terms of indicating typical irregularities and the possibility of their elimination in characteristically determined objects.

Such activities allow achieving higher energy efficiency and proper, pro-ecological functioning of the objects under consideration.

\footnotetext{
* Corresponding author: Karol.Bednarek@put.poznan.pl
} 


\section{Impact of disturbances and energy losses in public facilities supply networks}

The most advantageous form of energy is electrical energy, which can be easily produced, transferred, stored and used (processed for other types of energy) [1,7-9]. The majority of used electrical equipment is supplied from the power grid. Due to the increase in the technical sophistication of the operated equipment, the use of an increasing number of non-linear elements, complex management systems (controlling) as well as passive elements, transient (switching) states, dynamic load switching, discretized, impulsive energy consumption are appearing, which cause electromagnetic disturbances and energy losses [6, 10-16]. The resulting disturbances in the final effect may cause accelerated degradation and the need to replace the equipment, which is associated with increasing utilization problems. In addition, they cause additional energy losses.

Human in their economic and existential activities make many choices optimizing them [17-21]. They use various mathematical methods, apply appropriately selected technical means, and make decisions based on knowledge or well-established experience or resulting from specific premises related to the undertaken activities. People try to achieve the objectives in the simplest possible way, limiting the consumption of raw materials and energy, involving as little technical and human resources as possible, eliminating the negative impact of the technical infrastructure on the environment (including other systems operating in the environment) [17-23]. One of the elements of such optimal functioning is limiting the impact of electromagnetic disturbances and energy losses generation in devices and systems used in various types of public facilities.

The public buildings have specific character resulting from the specificity of their operation and related technical infrastructure [24-26]. They use devices and systems characteristic for their operation profile, the functioning of which is associated with proper energy consumption and losses, as well as with specific types and levels of electromagnetic disturbances. In production factories, the nature of the energy receivers is usually resistiveinductive, associated with the use of energy and inductive reactive power consumption by motors, transformers and other electromagnetic converters. However, there is a large group of objects having a resistive-capacitive character. That group includes office buildings, banks, shopping malls, and computing centers (IT facilities), where IT equipment and energy-saving lighting are used, and therefore devices that use capacitive reactive power in addition to active power. The disturbances in these units are mainly related to the pulse energy consumption, the use of non-linear elements (deforming the currents and voltages waveforms), as well as dynamic load switching.

Among the disturbances occurring and acting in $\mathrm{AC}$ power grids, the most frequent are current and voltage strains (higher harmonics) [6, 24-33]. Their impact is related to the generation of energy losses related to the power of deformation (geometric sum of active and reactive power of higher harmonics), overheating of components and devices resulting from harmonics of the sequence of zero and opposite order, the formation of resonances and their effects, disrupting the correct work of the equipment located close to the conductive elements (as a result of electromagnetic coupling), as well as equipment damaging and its insulating elements, etc. These effects are unfavorable to users for technical, economic and ecological reasons and should be eliminated.

Reduction of energy consumption (improvement of energy balance) in public units can be achieved by eliminating deformation power, limiting the occurrence of power losses, reactive power compensation, as well as generating energy from renewable sources. Currently, energy from renewable sources is generated in different ways. Wind turbines, photovoltaic modules as well as tile roof solar cells are commonly used. Various systems are used to improve the efficiency of converting light or wind energy into electricity. Their 
connection to a building supply system affects the energy balance, but also has impact on disturbances in the supply network of the building under consideration [1, 24, 34-38].

From the considerations it is clear that analyzed issues related to limiting: the impact of electromagnetic disturbances (mainly higher harmonics in power supply networks), the generation of power losses and reactive power consumption are very important because they affect the proper functioning, ecology and energy efficiency of public buildings.

\section{Results of current and voltage distortions tests and power balances in public facilities networks}

In order to demonstrate the diversity of energy receivers' usage in public facilities and the specificity of energy conversion in their systems, the paper presents the results of power consumption tests and current and voltage strains in characteristically different objects, such as: bank building, office and warehouse facility and IT laboratory. The values of currents, voltages and active, reactive and apparent power consumption in individual phases of their power supply systems as well as the total harmonic distortion (THD) ratios and the content of individual harmonics of currents and voltages in supply networks of these public units were investigated $[10,24,25]$.

\subsection{Power balance and current deformation in the bank's building network}

One of the objects that were tested for energy quality was the bank building. The main elements of the electrical equipment included in the network are: $30 \mathrm{kVA}$ uninterruptible power supply unit (low load - oversized, taking into account the future infrastructure development, supply the server room, 23 computers and other small equipment), cash machine, 4 air conditioning systems, energy-saving lighting systems and small office equipment. The results of the research carried out in the bank's building network are shown in Figures 1-2.

a)

\begin{tabular}{|c|c|c|c|c|}
\hline \multicolumn{5}{|c|}{ Moc i energia } \\
\hline \multicolumn{2}{|c|}{ FUND } & \multicolumn{2}{|c|}{ 0:00:07 } & 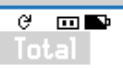 \\
\hline \multirow[t]{2}{*}{$\begin{array}{l}\text { kW } \\
\text { kUA } \\
\text { kURR } \\
\text { PF } \\
\text { Cos } \\
\text { Rrms }\end{array}$} & $\begin{array}{r}1.35 \\
1.67 \\
+0.99 \\
0.79 \\
0.81 \\
7.2\end{array}$ & $\begin{array}{r}2.56 \\
2.91 \\
+1.37 \\
0.87 \\
0.88 \\
12.3\end{array}$ & $\begin{array}{r}3.03 \\
3.11 \\
+0.69 \\
0.97 \\
0.97 \\
13.2\end{array}$ & $\begin{array}{r}6.95 \\
7.69 \\
+\quad 3.05 \\
0.89\end{array}$ \\
\hline & L1 & L2 & L3 & \\
\hline \multirow{2}{*}{$\begin{array}{l}\text { Urms } \\
03 / 06 / 14\end{array}$} & 237.4 & 238.9 & 237.8 & \\
\hline & 13:29:09 & $230 \mathrm{U} 50 \mathrm{H}$ & IZ 3. WYE & EN50160 \\
\hline PREU & BACK & HEXT & РRINT & |ms: : :-.... \\
\hline
\end{tabular}

b)

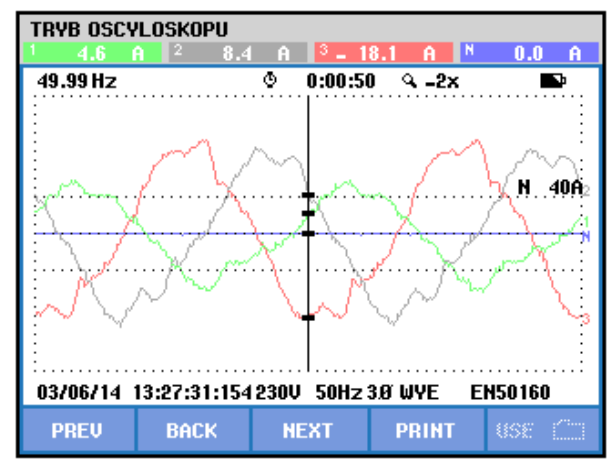

Fig. 1. Results of energy quality measurements in the bank's building network: a) values of voltages, currents, active, reactive and apparent power, b) current waveforms in individual phases of the system.

Figure $1 \mathrm{~b}$ presents the current waveforms for individual phases of the power supply system in a bank building. They are deformed from sinusoidal waveforms. The $\mathrm{THD}_{\mathrm{I}}$ factor for the whole network is around $25 \%$ (Figure $2 \mathrm{a}$ ). The circuits introducing the strongest distortions are IT devices (computers, servers, printers, etc.). The $\mathrm{THD}_{\mathrm{I}}$ coefficient in their case exceeds $60 \%$ (Figure 2b). In all considered cases, the dominant are 3, 5 and 7 harmonics. In the power supply network a large amount of capacitive reactive power is visible 
(Figure 1a). Reactive power is at the level of $44 \%$ of the useful (active) power value. It is mainly related to the functioning of impulse power supplies in IT equipment and energysaving lighting.

a)

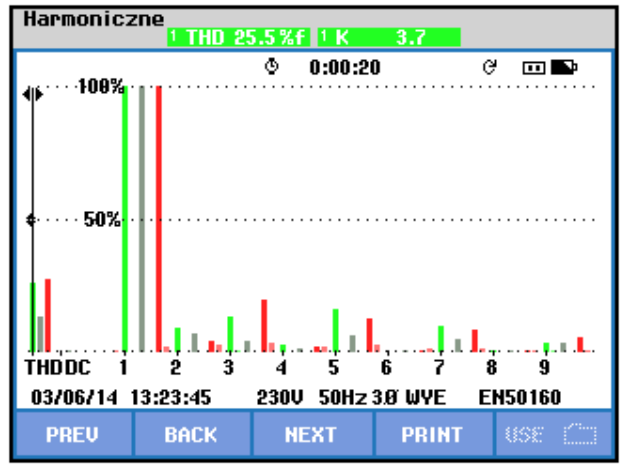

b)

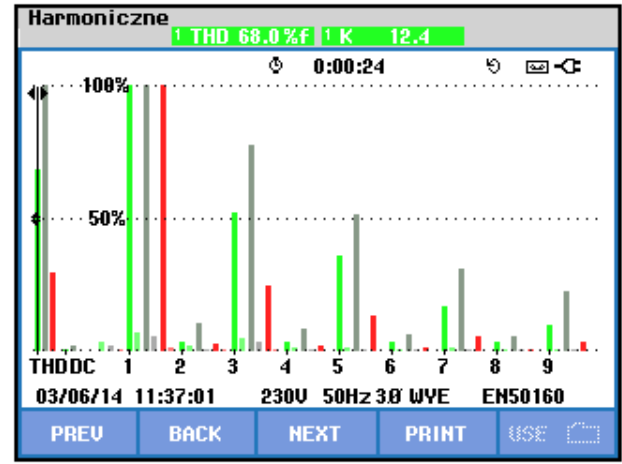

Fig. 2. Results of energy quality measurements in the bank's building network - harmonic spectral characteristics: a) phase currents in the entire network, b) phase currents in the IT part.

\subsection{Power consumption and current distortion research in the IT laboratory network}

Partially similar electrical equipment occurs in a computer laboratory operating at the Electrical Engineering Department of the Poznan University of Technology (designed for students' classes). The main energy receivers were computer sets. In a separated phase (L2) of the power supply system, 15 desktop computers (PCs) with their monitors were operated. This object is representative, because illustrates power balances and distortions of currents in networks of various types of IT units or those in which the main equipment are computers and cooperating equipment. The elements that determine the character of the power consumed and the shape of the power consumed from the power supply system are, above all, impulse power supplies commonly used in IT equipment. The results of the tests carried out in the laboratory network are shown in Figures 3-4.

a)

\begin{tabular}{|c|c|c|c|c|}
\hline \multicolumn{5}{|c|}{ Power \& Energy } \\
\hline & $\begin{array}{l}\text { FULL } \\
\text { L1 }\end{array}$ & $\begin{array}{l}\text { 0:00:0 } \\
\text { L2 }\end{array}$ & L3 & 与 四町 \\
\hline $\begin{array}{l}\text { kW } \\
\text { kUR } \\
\text { kURR } \\
\text { PF } \\
\text { Cos } \\
\text { Rrms }\end{array}$ & $\begin{array}{r}0.30 \\
0.31 \\
+\quad 0.07 \\
0.97 \\
0.98 \\
1.4\end{array}$ & $\begin{array}{r}0.87 \\
1.05 \\
0.58 \\
0.83 \\
1.00 \\
4.7\end{array}$ & $\begin{array}{r}0.14 \\
0.20 \\
+\quad 0.14 \\
0.71 \\
1.00 \\
0.9\end{array}$ & $\begin{array}{r}1.31 \\
1.56 \\
+0.80 \\
0.84\end{array}$ \\
\hline $\begin{array}{l}\text { Urms } \\
14 / 01 / 16\end{array}$ & $\begin{array}{c}\text { L1 } \\
\text { 225.0 } \\
13: 11: 44\end{array}$ & $\begin{array}{c}\text { Lट } \\
224.8 \\
230050 \mathrm{~Hz}\end{array}$ & $\begin{array}{c}\text { L3 } \\
225.8 \\
38 \text { WYE }\end{array}$ & EN50160 \\
\hline PREU & BACK & HEXT & PRINT & 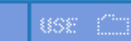 \\
\hline
\end{tabular}

b)

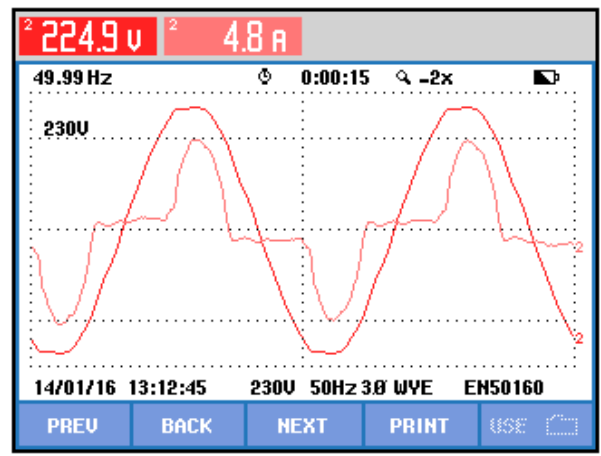

Fig. 3. Results of energy quality measurements in the IT laboratory supply network: a) values of voltages, currents, active, reactive and apparent power, b) current and voltage time waveforms in the L2 phase. 
The current in these devices is pulse-drawn (in the voltage sinusoid peak) and is strongly distorted (Figure $3 \mathrm{~b}$ ). The $\mathrm{THD}_{\mathrm{I}}$ factor is at a level exceeding $60 \%$ (Fig. 4), and the dominant harmonics are 3 and 5 . The reactive capacitive power in this system exceeds $60 \%$ of the useful power (Fig. 3a). The obtained research results are analogous to those in the IT part of the bank building.

a)

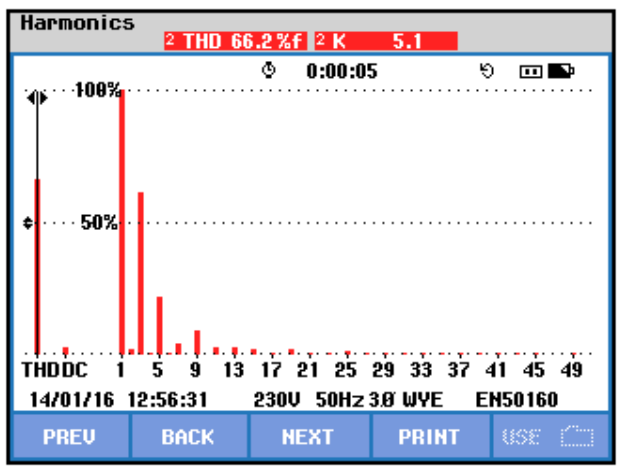

b)

\begin{tabular}{|c|c|c|c|c|}
\hline \multicolumn{5}{|c|}{ HARMONICS TRBLE } \\
\hline Uolt & L1 & $\begin{array}{l}\mathbf{0 : 0} \\
\mathrm{L} 2\end{array}$ & L3 & 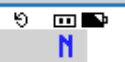 \\
\hline $\begin{array}{l}\text { THD\%f } \\
\text { H3\%f } \\
\text { H5\%f } \\
\mathrm{H} 7 \% \mathrm{f}\end{array}$ & $\begin{array}{l}2.3 \\
1.1 \\
1.4 \\
1.2\end{array}$ & $\begin{array}{l}2.3 \\
1.0 \\
1.4 \\
1.1\end{array}$ & $\begin{array}{l}2.0 \\
0.8 \\
1.1 \\
1.1\end{array}$ & $\begin{array}{r}391.9 \\
375.4 \\
17.6 \\
21.8\end{array}$ \\
\hline $\begin{array}{l}\text { Pmp } \\
H 3 \% \mathrm{f} \\
\mathrm{H5 \% f} \\
\mathrm{H} \% \mathrm{f}\end{array}$ & $\begin{array}{l}\mathrm{L1} \\
3.5 \\
11.2 \\
1.2\end{array}$ & $\begin{array}{r}\text { L2 } \\
61.4 \\
21.8 \\
4.4\end{array}$ & $\begin{array}{l}L 3 \\
80.4 \\
50.1 \\
18.6\end{array}$ & $\begin{array}{c}N \\
83.6 \\
79.8 \\
82.2\end{array}$ \\
\hline \multicolumn{2}{|c|}{ 14/01/16 12:56:31 } & 230050 & g WYE & EN50160 \\
\hline PREU & BACK & MEXT & PRINT & 世s: \\
\hline
\end{tabular}

Fig. 4. Results of energy quality measurements in the IT laboratory supply network: a) spectral characteristics of current harmonics in L2 phase, b) content of the most important currents and voltages harmonics in individual phases.

\subsection{Analysis of the power and current deformation in the office and warehouse building network}

The office and warehouse building is specific in terms of energy quality test. In office part, there is electrical equipment similar to the equipment in the bank building (IT equipment, energy-saving lighting systems and small office equipment). The test results obtained in this part of the facility were also analogous to those in the bank's building. However, devices that are connected to the network in the storage part are the dominating electrical loads of the facility. The most important of them are: energy-efficient lighting systems of the building's halls, lighting systems of 120 storage alleys with dimmers and automatic switching with presence sensors, specialized internal transport in the form of self-propelled rail carts with high-speed elevators, energy-saving ventilation and air-conditioning systems and a small production part with several different machines. In addition, in the facility operates a photovoltaic installation. Due to its operation energy balances and current distortion levels taken from the power grid vary during sunshine and strong cloud cover periods. The results of measurements carried out in this system are shown in Figures 5-7.

The analysis of energy quality and power balance in the office and warehouse facility [24] has shown that solar power supply covers part of the useful energy consumption (active). Reactive power and deformation power from network does not change in periods of insolation and cloud cover (different energy production by photovoltaic modules). During insolation, the current deformation in the system is stronger $\left(\mathrm{THD}_{\mathrm{I}}\right.$ is at the level exceeding $60 \%$, because the undeformed component of the current is smaller - Fig. $5 \mathrm{~b}$ and Fig. 6a), however, with a lower value of the current consumed from the AC grid $(50 \mathrm{~A}$, because some part of the current comes from a PV installation).

In the cloud cover period (lower efficiency of PV modules) the deformation of the current is lower $\left(\mathrm{THD}_{\mathrm{I}}\right.$ is at the level of about $30 \%$ - Fig. 6b), and the phase currents exceed $100 \mathrm{~A}$. In both cases, the 3,5 and 7 harmonics are dominant. In the system, the inductive reactive 
power consumption takes place at the level exceeding $70 \%$ of active power (Fig. 5a) during insolation period, and about $30 \%$ during the cloud cover.

a)

\begin{tabular}{|c|c|c|c|c|}
\hline \multicolumn{5}{|c|}{ Power \& Energy } \\
\hline & FUND & L2:00:0 & L3 & Total \\
\hline $\begin{array}{l}\text { kU } \\
\text { kUA } \\
\text { kUAR } \\
\text { PF } \\
\text { Cos } \\
\text { Rrms }\end{array}$ & $\begin{array}{r}9.8 \\
11.3 \\
5.7 \\
0.81 \\
0.87 \\
53\end{array}$ & $\begin{array}{r}5.7 \\
9.2 \\
7.2 \\
0.55 \\
0.62 \\
45\end{array}$ & $\begin{array}{c}10.2 \\
11.9 \\
6.2 \\
0.80 \\
0.86 \\
56\end{array}$ & $\begin{array}{l}25.7 \\
32.4 \\
19.0 \\
0.73\end{array}$ \\
\hline $\begin{array}{l}\text { Urms } \\
02 / 08 / 17\end{array}$ & $\begin{array}{c}\mathrm{L} 1 \\
230.5 \\
12: 42: 46\end{array}$ & $\begin{array}{c}\text { L2 } \\
232.1 \\
2300 \quad 50 \mathrm{~Hz}\end{array}$ & $\begin{array}{c}\text { L3 } \\
229.5 \\
3.8 \text { WYE }\end{array}$ & EN50160 \\
\hline $\begin{array}{l}\text { UOLTAGE } \\
\Lambda \\
\Lambda\end{array}$ & & ENERGY & TREKD & $\frac{\text { HOLD }}{\text { RIUH }}$ \\
\hline
\end{tabular}

b)

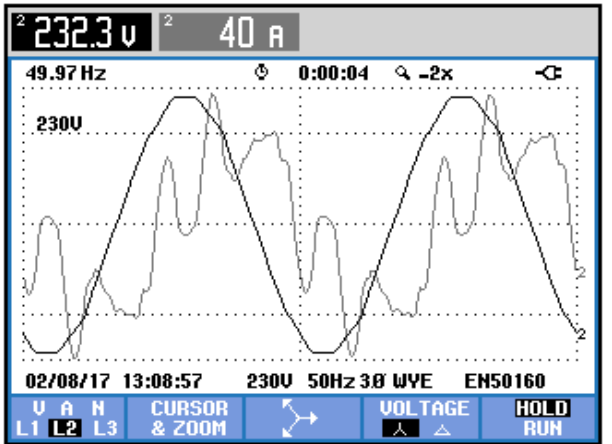

Fig. 5. Results of energy quality measurements in the office and warehouse facility power supply network: a) values of voltages, currents, active, reactive and apparent power during the insolation, b) voltage and current time waveforms in the object during the insolation.

a)

\begin{tabular}{|c|c|c|c|c|}
\hline \multicolumn{5}{|c|}{ HARMONICS TRBLE } \\
\hline Pm & 11 & $0^{0: 00: 0}$ & 13 & 与柬口: \\
\hline $\begin{array}{l}\text { THD\%f } \\
\text { H3\%f } \\
\text { H5\%f } \\
\text { H7\% } \\
\text { H9\% } \\
\text { H1 } 1 \% \text { f } \\
\text { H13\%f } \\
\text { H15\%f }\end{array}$ & $\begin{array}{r}68.1 \\
53.9 \\
28.3 \\
25.1 \\
9.1 \\
13.1 \\
1.8 \\
2.3\end{array}$ & $\begin{array}{r}61.9 \\
13.6 \\
49.4 \\
32.7 \\
3.6 \\
9.1 \\
1.9 \\
0.6\end{array}$ & $\begin{array}{r}65.2 \\
20.0 \\
49.5 \\
33.0 \\
9.6 \\
11.8 \\
4.2 \\
2.7\end{array}$ & $\begin{array}{r}86.3 \\
73.4 \\
35.8 \\
21.7 \\
10.3 \\
6.7 \\
7.6 \\
4.9\end{array}$ \\
\hline \multicolumn{2}{|c|}{ 02/08/17 12:26:29 } & $230050 \mathrm{~Hz}$ & WYE & EN50160 \\
\hline " & & $\begin{array}{l}\text { HAPMOHIC } \\
\text { GRAPHC }\end{array}$ & TREND & $\frac{\text { HOLD }}{\text { RUH }}$ \\
\hline
\end{tabular}

b)

\begin{tabular}{|c|c|c|c|c|}
\hline \multicolumn{5}{|c|}{ HARMONICS TABLE } \\
\hline Amp & L1 & \multicolumn{2}{|c|}{ 0:01:14 } & 罯 $\alpha=$ \\
\hline $\begin{array}{l}\text { THD\%f } \\
\text { H3\%f } \\
\text { H5\% } \\
\text { H7\% } \\
\text { H9\% } \\
\text { H1 } 1 \% \text { f } \\
\text { H13\%f } \\
\text { H15\%f }\end{array}$ & $\begin{array}{r}20.6 \\
15.1 \\
10.2 \\
8.3 \\
1.6 \\
3.7 \\
0.4 \\
0.8\end{array}$ & $\begin{array}{r}32.7 \\
7.5 \\
26.0 \\
17.1 \\
0.9 \\
5.8 \\
2.0 \\
0.6\end{array}$ & $\begin{array}{r}29.9 \\
6.8 \\
23.3 \\
15.8 \\
.7 .7 \\
5.7 \\
1.9 \\
1.8\end{array}$ & $\begin{array}{r}82.0 \\
67.7 \\
38.6 \\
18.2 \\
5.0 \\
9.7 \\
10.2 \\
6.4\end{array}$ \\
\hline \multicolumn{2}{|c|}{ 02/08/17 $12: 54: 51$} & \multicolumn{3}{|c|}{$230 \mathrm{U} 50 \mathrm{~Hz} 3.8$ WYE } \\
\hline 由 & & $\begin{array}{l}\text { HARMOHIC } \\
\text { GRAPPHC }\end{array}$ & TREEID & HOLD \\
\hline
\end{tabular}

Fig. 6. Results of energy quality measurements in the office and warehouse facility power supply network - content of the most important harmonics of currents in individual phases: a) during the insolation, b) during cloud cover [24].

a)

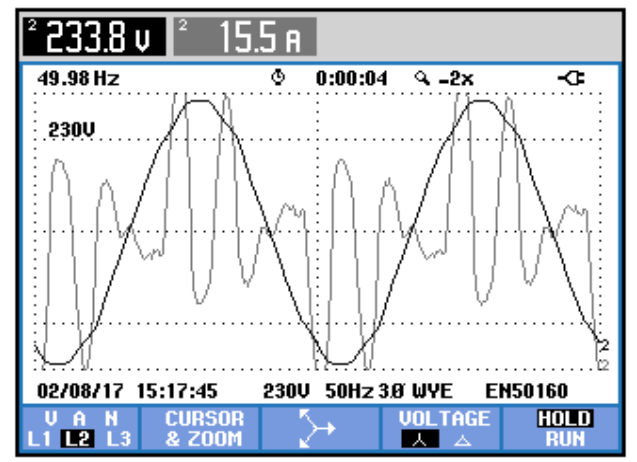

b)

\begin{tabular}{|c|c|c|c|c|}
\hline \multicolumn{5}{|c|}{ HARMONICS TRBLE } \\
\hline Amp & L1 & \multicolumn{2}{|c|}{ 0:00:16 } & 与四水 \\
\hline $\begin{array}{l}\text { THD\%f } \\
\text { H3\%f } \\
\text { H5\%f } \\
\text { H7\%f } \\
\text { H9\%f } \\
\text { H1 } 1 \% \text { f } \\
\text { H13\%f } \\
\text { H15\%f }\end{array}$ & $\begin{array}{r}177.1 \\
20.8 \\
138.0 \\
102.2 \\
2.2 \\
31.0 \\
5.1 \\
7.0\end{array}$ & $\begin{array}{r}173.5 \\
19.9 \\
133.8 \\
102.3 \\
2.5 \\
29.8 \\
8.9 \\
7.6\end{array}$ & $\begin{array}{r}134.2 \\
1.8 \\
107.8 \\
74.9 \\
3.3 \\
22.6 \\
3.7 \\
1.5\end{array}$ & $\begin{array}{r}26.1 \\
11.2 \\
15.4 \\
10.1 \\
7.5 \\
8.3 \\
4.4 \\
4.1\end{array}$ \\
\hline \multicolumn{2}{|c|}{ 02/08/17 $\quad 15: 20: 34$} & \multicolumn{2}{|c|}{2300 $50 \mathrm{~Hz} 3.8$ WYE } & EH50160 \\
\hline " & & $\begin{array}{l}\text { HARMOOHIT } \\
\text { GRAPH }\end{array}$ & TREND & \begin{tabular}{l|l} 
HOLD \\
RUIH
\end{tabular} \\
\hline
\end{tabular}

Fig. 7. Results of energy quality measurements in the ventilation and air-conditioning circuit of an office and warehouse facility: a) current and voltage time waveforms in the L2 phase, b) content of the most important harmonics of currents in individual phases. 
In all analyzed cases it is recommended to use reactive power compensation (taking into account its character) as well as passive or active higher harmonic filters.

\section{Final notes and conclusion}

The office and warehouse facility has resistive-inductive character. Strong deformations of the current from the power grid were observed. It was caused by ventilation and airconditioning devices, in which advanced control systems for their efficiency were used. Similar equipment is also used in many production institutions. There are working motors with adjustable rotational speed, electronic systems controlling the performance of devices, numerically controlled machines, etc. In these conditions, in addition to the reactive power compensation systems, higher harmonic filters should be used. In case of very large powers, it is worth to use the separation of receivers introducing the strongest deformations and use active filters in them - the most effective in eliminating the distortions (higher harmonics) of currents and voltages.

In the bank building and in the computer laboratory, the character of the energy receivers was resistive-capacitive. There were also strong current deformations in the networks of these objects. Also in these cases, filtering systems that limit the consumption of deformation power (influence of higher harmonics) and a reactive power compensation systems should be used, but with an opposite character than in the case of an office and warehouse facility or production plants.

Due to reduction of current and voltage deformations (higher harmonic content), reduction of energy consumption from the AC grid through the facility (by eliminating the deformation power consumption) can be obtained. It also allows limiting energy losses occurring in devices related to generation and transmission of energy as a result of reducing the current flowing through them. This results in the improvement of the energy efficiency of the entire system (economic and technical benefits) and the reduction of heat emission from the elements to the environment (ecological benefits).

\section{References}

1. A. Bugała, K. Bednarek, L. Kasprzyk, A. Tomczewski, E3S Web of Conferences 19, 01002 (2017)

2. P. Jadwiszczak, E3S Web of Conferences 17, 00032 (2017)

3. M. Knapik, E3S Web of Conferences 17, 00039 (2017)

4. T. Malec, T. Boczar, D. Wotzka, P. Frącz, E3S Web of Conferences 19, 01001 (2017)

5 J. Wawrzyńczyk, Prz. Elektrotechniczny 93, 11, 14-16 (2017)

6. X. Wilsun, L. Xian, L. Yilu, IEEE Trans. Power Deliv. 18, 1 (2003)

7. K. Bednarek, R. Nawrowski, A. Tomczewski, Prz. Elektrotechniczny 84, 1, 62-64 (2008)

8. D. Burzyński, L. Kasprzyk, E3S Web of Conferences 14, 01041 (2017)

9. L. Kasprzyk, Eksploat. Niezawodn. 19, 229-236 (2017)

10. K. Bednarek, Prz. Elektrotechniczny 90, 12, 188-191 (2014)

11. J. Jajczyk, A. Dobrzycki, M. Filipiak, D. Kurz, E3S Web of Conferences 19, 01027 (2017)

12. M. Lebioda, J. Rymaszewski, E. Korzeniewska, Journal of Physics Conference Series 494, 012018 (2014) 
13. A. Dobrzycki, S. Mikulski, W. Opydo, International Conference on High Voltage Engineering and Application (ICHVE, 1-4, 2014)

14. J. Rymaszewski, M. Lebioda, E. Korzeniewska, Prz. Elektrotechniczny 88, 2B, 183-186 (2012)

15. D. Typańska, A. Maćkowiak, K. Sieczkarek, Prz. Elektrotechniczny 92, 4, 38-42 (2016)

16. M. Wciślik, Prz. Elektrotechniczny 90, 2, 136-140 (2014)

17. K. Bednarek, J. Jajczyk, Prz. Elektrotechniczny 85, 12, 29-32 (2009)

18. A. Lewicki, A. Bugała, H. Piekarska-Boniecka, A. Lewicka, P. Boniecki, M. Cieślik, International Conference on Chemical and Biological Sciences (ICCBS 2016)

19. L. Kasprzyk, K. Bednarek, Prz. Elektrotechniczny 85, 12, 65-68 (2009)

20. Ł. Knypiński, L. Nowak, A. Demenko, COMPEL 34, 2, 448-455 (2015)

21. R. Nawrowski, K. Bednarek, A. Tomczewski, International Conference on Parallel Computing in Electrical Engineering (PARELEC, 218-222, 2000)

22. J. Jajczyk, Computational Problems of Electrical Engineering (IEEEXplore, 1-3, 2016)

23. L. Kasprzyk, A. Tomczewski, K. Bednarek, Prz. Elektrotechniczny 87, 12b, 82-85 (2011)

24. D. Typańska, K. Bednarek, Prz. Elektrotechniczny 93, 12, 63-66 (2017)

25. L. Kasprzyk, K. Bednarek, Poznan University of Technology Academic Journals, Electrical Engineering 86, 291-300 (2016)

26. A. Koziorowska, J. Bartman, Prz. Elektrotechniczny 90, 1, 136-140 (2014)

27. K. Bednarek, L. Kasprzyk, Prz. Elektrotechniczny 88, 12B, 236-239 (2012)

28. IEEE Std 1459-2010 Standard Definitions for the Measurement of Electric Power Quantities Under Sinusoidal, Nonsinusoidal, Balanced, or Unbalanced Conditions; IEEE, New York, 2010

29. M. Maciążek, M. Pasko, Prace Instytutu Elektrotechniki 242, 149-161 (2009)

30. M. Pasko, A. Lange, Prz. Elektrotechniczny 86, 126-129 (2010)

31. Ł. Putz, M. Kurzawa, Computational Problems of Electrical Engineering (IEEEXplore, 2016)

32. Ł. Putz, D. Typańska, Prz. Elektrotechniczny 90, 3, 111-114 (2014)

33 X. Wilsun, L. Yilu, IEEE Trans. Power Deliv. 15, 2 (2000)

34. A. Bugała, G. Frydrychowicz-Jastrzębska, Z. Zbytek, J. Dach, D. Janczak, MATEC Web of Conferences $\mathbf{5 9}$ (2016)

35. J. Dach, G. Frydrychowicz-Jastrzębska, A. Bugała, D. Janczak, P. Boniecki, International Multidisciplinary Scientific Geoconference (SGEM, 337-344, 2016)

36. D. Janczak, W. Czekała, J. Dach, A. Bugała, G. Frydrychowicz-Jastrzębska, M. Zaborowicz, Internat. Conference on Energy and Environment, (ICEE, 721-727, 2015)

37. G. Trzmiel, Eksploat. Niezawodn. 19, 516-521 (2017)

38. K. Skowronek, G. Trzmiel, Prz. Elektrotechniczny 83, 11, 108-110 (2007) 